\title{
KONSTRUKSI METODOLOGI FIQH AL-BUKHĀRĪ DAN KEGAGALAN PEMBENTUKAN MAZHAB
}

\author{
Muh. Fathoni Hasyim \\ Universitas Islam Negeri Sunan Ampel Surabaya, Indonesia \\ E-mail: mufah.hasyim@gmail.com
}

\begin{abstract}
The popularity of al-Bukhārī as the expert of hadith is indisputable; he reached his top figure; his name becomes a guarantee of his hadith validity; besides, he is also well-known as the expert of Islamic law (faqih). However, his expertise in Islamic law is often disregarded. In fact, the authority of al-Bukhārī in Islamic law reaches its peak as an absolute mujtahid (mujtahid mutlaq). This phenomenon raised some questions. Firstly, is al-Bukhārī affiliated with one of established Sunnī madhhabs? When a mujtahid has reached his absolute rank, he needs of his own fiqh methodology construction, other than following another methodology. Secondly, does al-Bukhārī have his own methodology? Frankly, an absolute mujtahid has an opportunity to establish his own madhhab ordained to his name. Thirdly, why is alBukhārìss madhhab unpopular among Sunn̄̄ maddhabs? This article found that al-Bukhārī is not affiliated to certain madhhabs, then explored the methodology formation as well as other factors underlying the failure of formation of al-Bukhārì's madhhab.
\end{abstract}

Keywords: al-Bukhārī; Islamic law methodology; mujtahid mutlaq.

\section{Pendahuluan}

Muhammad b. Ismāồil al-Bukhārī (194-256 H), atau lebih dikenal dengan al-Bukhārī, adalah sosok yang menguasai multidisiplin ilmu, terutama di bidang keilmuan hadīth dan fiqh. Keahlian al-Bukhārī di bidang hạaīth cukup populer, bahkan namanya adalah jaminan akan kesahihan hadīth. Namun, berbeda halnya keahliannya pada bidang yang disebut kedua, yang tidak 
sepopuler yang pertama, meskipun otoritas al-Bukhārī di bidang ini juga telah mencapai puncaknya.

Para ulama klasik dan modern di dunia Islam dan Barat jarang bahkan hampir tidak ada yang menyinggung fiqh dan metodologi fiqh al-Bukhārī dalam karya-karyanya, seperti Joseph Schacht dan Wael B. Hallaq, tidak memberikan ruang kajian dalam buku-buku yang disusunnya. Bahkan, Christopher Melchert, pengkaji traditionist-jurisprudents abad kesembilan, sama sekali tidak menyinggung metodologi fiqh al-Bukhārīi. ${ }^{1}$ Padahal, dalam kitabkitab klasik terdapat beberapa testimoni dan apresiasi terhadap keahlian al-Bukhārī di bidang fiqh, dan beberapa sebutan ataupun gelar telah disematkan kepadanya, seperti Sayyid al-Fuqahä', Faqīh hädhih al-Ummah, buwa afqah khalq Alläh fi ramaninā, Täj al-Fuqahä, Fa's fi al-Fiqh, dan Mujtahid Mutlaq; keahliannya di bidang fiqh disejajarkan dengan Mālik, sementara di bidang fiqh dan hạīith melebihi Isḥāq b. Rāhawayh dan Aḥmad b. Hanbal. ${ }^{2}$

Sementara itu, kajian terkait al-Bukhārī lebih banyak terfokus pada keahliannya di bidang hadīth, terutama telaah pada karya monumentalnya, al-Jāmi' al-Sahīh, baik dalam bentuk buku maupun karya ilmiah lainnya, seperti Fiqh al-Da'wah fi Sahīh al-Imām alBukbārì oleh Sa'īd b. 'Alī b. Wahf al-Qahțānīi's Fiqh al-Imām alBukhärì fì al-Zakāh oleh Ibtisām b. Muḥammad b. Aḥmad alGhāmidī; Telaah Ulang atas Kriteria Kesabihan Hadith-Hadith al-Jämi" al-Sabīh oleh Muhibbin; ${ }^{5}$ Kritik Terhadap Kitab Shabih al-Bukhari dan Shabih Muslim oleh Marzuki; ${ }^{6}$ Health and Medicine in the Islamic Tradition Based on the Book of Medicine (Kitab al-Tibb) of Sabih al-

\footnotetext{
${ }^{1}$ Scott C. Lucas, "The Legal Principles of Muhammad b. Ismā'īl al-Bukhārī and Their Relationship to Classical Salafi Islam”, Islamic Law and Society, Vol. 13, No. 3 (2006), 289-324.

2 'Abd al-Sattār al-Shaykh, al-Imām al-Bukhäri: Ustädh al-Ustädhìn wa Imām al-

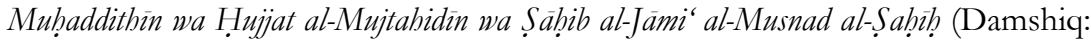
Dār al-Qalam, 2007), 249.

3 Sa'īd b. 'Alī b. Wahf al-Qaḥtānī, Fiqh al-Da'wah fì Sahīḥ al-Imām al- Bukhārī (Mekah: Kementerian Wakaf, Dakwah, dan Irsyad, 1999).

${ }^{4}$ Ibtisām b. Muḥammad b. Aḥmad al-Ghāmidī, "Fiqh al-Imām al-Bukhārī fì alZakāh” (Tesis--Universitas Umm al-Qurā Mekah, t.th.).

5 Muhibbin, "Telaah Ulang atas Kriteria Kesahihan Hadith-Hadith al-Jāmi' alȘahih” (Disertasi--UIN Sunan Kalijaga Yogyakarta, 2004).

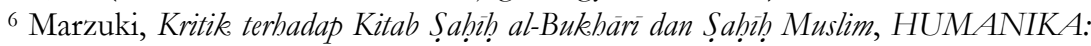
Kajian Ilmiah Mata Kuliah Umum, Vol. 6, No. 1 (2006), 26-38.
} 
Bukhari oleh Nurdeen Deuraseh; ${ }^{7}$ Tibbonto: Knowledge Representation of Prophet Medicine (Tibb al-Nabawn) oleh Asma al-Rumkhani et al.; ${ }^{8}$ Abl al-Hadith Metodologies on Qur'anic Discourse in the Ninth Century: $A$ Comparative Analisys of Ibn Hanbal and al-Bukhari oleh Ahmad Sanusi Azmi, ${ }^{9}$ dan karya-karya ilmiah lainnya.

Al-Bukhārī adalah seorang ulama yang sangat produktif, yang menulis beberapa kitab dalam berbagai bidang keilmuan, yang di antaranya adalah Qadàya al-Sahäbah wa al-Täbi în Aqäwilubum, alJämi‘ al-Sahịh, al-Adāb al-Mufrad, Birr al-Wälidayn, al-Tärìkh al-Kabìr, al-Tärikeh al-Awsat, al-Tārikeh al-Saghìr, al-D̦'afä', al-Jāmi' al-Kabir, alMusnad al-Kabir, al-Tafsìr al-Kabir, Khalq Af'äl al-Tbäd, al-Tläl fì alHadìth, al-Wuḅdàn, al-Mabsüt, al-Fawä̀id, dan lain-lain. Dari beberapa judul kitab di atas, tampak bahwa al-Bukhārī tidak hanya ahli di bidang hạaīth, tetapi juga fiqh, teologi, sejarah, tafsir, etika, dan lain-lainnya. Dari deretan kitab karya al-Bukhārī di atas, kitab pertama yang disusun pada usianya yang relatif muda (18 tahun) adalah kitab fiqh, yaitu Qadàyā al-Sahäbah wa al-Täbirin wa Aqäwilubum, bukan kitab hadìth atau lainnya. Kitab fiqh al-Bukhārī lainnya adalah Raf' al-Yadayn fi al-Saläh, Khayr al-Kaläm fi al-Qiräab Khalf al-Imàm, al-Ashribah, dan al-Hibah. Kitab-kitab fiqh tersebut merupakan bukti otentik keahlian al-Bukhārī di bidang fiqh. Bahkan, fakta bahwa kitab hadīth al-Jāmi al-Ṣahịh-nya disusun dengan menggunakan sistematika kitab fiqh juga turut membuktikan keahliannya di bidang tersebut.

Para ulama berselisih pendapat tentang afiliasi dan posisi alBukhārī di bidang fiqh, di mana masing-masing mazhab mengklaim al-Bukhārī sebagai pengikut mazhabnya, meskipun posisi al-Bukhārī sebagai pengikut (muqallid) belum ada kesepakatan. Ada yang menempatkan al-Bukhārī sebagai salah seorang tokoh

\footnotetext{
${ }^{7}$ Nurdeen Deuraseh, "Health and Medicine in the Islamic Tradition Based on the Book of Medicine (Kitab al-Tibb) of Sahih al- Bukhari", Journal of The International Society for History of Islamic Medicine (JISHIM), Vol. 5, No. 1 (2006), 214.

8 Asma al-Rumkhani at al., "Tibbonto: Knowledge Representation of Prophet Medicine (Tibb al-Nabawi)", Procedia Computer Science, Vol. 82 (2016), 138-142. 9 Ahmad Sanusi Azmi, "Ahl al-Hadith Metodologies on Qur'anic Discourse in the Ninth Century: A Comparative Analisys of Ibn Hanbal and al-Bukhari", dalam Online Journal Research in Islamic Studies, Vol. 4, No. 1 (2017), 17-26.
} 
mazhabnya pada level pertama, dan ada juga yang menyebutnya sebagai tokoh pada level kedua dalam mazhabnya. Padahal, posisi al-Bukhārī telah mencapai peringkat tertinggi, yaitu mujtahid mutlak (mujtahid mutlaq), sebuah tingkatan tertinggi dalam strata ijtihad, yang berarti telah memenuhi semua persyaratan sebagai mujtahid yang mandiri. ${ }^{10}$ Banyak disiplin ilmu yang harus dikuasai untuk mencapai strata ini, dan syarat yang paling utama adalah mempunyai konstruksi metodologi hukum Islam sendiri atau tidak menggunakan metode istinbat hukum mazhab lain.

Metodologi hukum Islam (usūl al-fiqh) adalah metode bepikir untuk istinbat atau menggali hukum Islam langsung dari sumber primernya. Hukum yang tersurat dan yang tersirat dalam sumber primer (al-Qur'ān dan al-Sunnah) tidak bisa ditemukenali hanya bermodal penguasaan satu atau dua macam disiplin keilmuan, sehingga diperlukan sejumlah ilmu yang dipersyaratkan bagi para mujtahid. Seorang mujtahid meskipun telah menguasai berbagai disiplin keilmuan, belum tentu dapat mencapai level tertinggi, sebelum ia mempunyai konstruksi metodologi sendiri. Oleh karena itu, al-Bukhārī sebagai mujtahid mutlak tentu mempunyai metodologi sendiri. Sampai di sini kemudian muncul beberapa persoalan; bagaimanakah konstruksi metodologi al-Bukhārī? Sebagaimana para pendiri mazhab yang lain, seorang mujtahid mutlak yang memiliki metodologi sendiri berpeluang untuk mendirikan mazhab yang biasanya dinisbahkan pada namaya, tetapi mengapa dalam sejarah hukum Islam tidak dikenal mazhab al-Bukhārī? Beberapa persoalan tersebutlah yang hendak dicari jawabannya dalam artikel ini, dan sekaligus yang membedakan dan menjadi kebaruan artikel ini dari pada karya-karya penelitian lain yang sudah ada seperti telah disebutkan di atas.

\section{Afiliasi Fiqh al-Bukhārī}

Silang pendapat terjadi di kalangan jurists tentang afiliasi fiqh alBukhārī, karena ia lahir setelah kokohnya pengaruh para ulama besar pendiri mazhab, terutama mazhab yang empat yang survive hingga kini, yaitu Ḥanafî, Mālik, Shāfícî̀, dan Aḥmad b. Ḥanbal. AlBukhārī belajar fiqh dan menghimpun hạdìth dari banyak guru,

\footnotetext{
10 Afwan Fanani, “Al-Suyuti dan Kontroversi Strata Ijtihad: Telaah atas Klaim Mujtahid Mutlak al-Suyuti dan Landasan Normatifnya”, Islamica: Jurnal Studi Keislaman, Vol. 2, No. 2 (2008), 116.
} 
termasuk dari para imam dan pengikut mazhab yang empat tersebut. Oleh karena itu, bisa dipahami bila para fuqab $\vec{a}$ ' berselisih pendapat tentang afiliasi mazhab al-Bukhārī.

Ulama Ḥanābilah mengklaim bahwa al-Bukhārī adalah pengikut dan tokoh mazhab Hanbalī. Ibn Abī Ya lā dalam Ṭabaqāt al-Hanābilah mencantumkan nama Muhammad b. Ismāî́l alBukhārī sebagai tokoh mazhab Hanbalī. ${ }^{11}$ Pengelompokan ini tak lebih karena al-Bukhārī hidup sezaman dengan Ibn Hanbal (w. 241 $\mathrm{H} / 875 \mathrm{M}$ ); ia pernah berkunjung ke Bagdad delapan kali, dan setiap kali ke Baghdad ia selalu meyempatkan diri mengunjungi Ibn Hanbal, dan ia meriwayatkan beberapa ḥadīth dari padanya. Dalam kitab tersebut, al-Bukhārī disebut sebagai sahabat sekaligus murid Ibn Hanbal. ${ }^{12}$

Klaim serupa disampaikan oleh beberapa ulama dari mazhab lain seperti al-Subkī. Dalam kitab Țabaqät al-Shäfirỹah al-Kubrā, ia memasukkan nama al-Bukhārī ke dalam jajaran tokoh mazhab Shāfíī, karena ketika tinggal di Hijaz, ia pernah belajar pada murid dan sahabat-sahabat al-Shāfíî, seperti al-Ḥumaydī (w. 219 H/837 M), Husayn al-Karabisī (w. 248 H/866 M), Abū Thawr (w. 246 H/864 M), al-Za'farānī (260 H/878 M) dan lain-lainnya, bahkan menurut al-Subkī, keahliannya di bidang fiqh tersebut diperoleh dari al-Humaydi. ${ }^{13}$

Ulama Mālikīyah juga memasukkan al-Bukhārī sebagai pengikut mazhabnya, karena ia meriwayatkan al-Muwatta' dari murid-murid Mālik, seperti 'Abd Allāh b. Yūsuf al-Tūnisī, Sa'īd b. 'Anbār, dan Ibn Bukhayr. ${ }^{14}$ Al-Bukhārī juga dimasukkan sebagai pengikut mazhab Ḥanafí, karena dia murid dari Ishạa b. Rāhawayh, seorang ahli di bidang hadīth dan fiqh mazhab Hanafî. Karena pengetahuan al-Bukhārī yang luas di dua disiplin ilmu tersebut, Ibn Hajar menyebutnya sebagai Amir al-Mu'minin fì al-

\footnotetext{
11 Ibn Abī Ya‘lā, "Tabaqat al-Hanābilah", al-Maktabah al-Shāmilah, Edisi 2; alMajmū'ah 46, Tarājim wa al-Ṭabaqah 15 (t.th.), 106-110.

12 Aḥmad b. 'Alī al-Khaṭīb al-Baghdādī, Tārikeh Baghdād (Kairo: Maktabat alKhanijīi, 1931), 19.

13 'Abd al-Wahhāb b. Taqī al-Dīn al-Subkī, Țabaqat al-Shāfi'ȳyah al-Kubrā, Vol. 2 (Mesir: al-Ḥasinīyah al-Mișrīyah, t.th.), 3-4.

14 'Abd al-Majīd Hāshim al-Ḥusaynī, al-Imām al-Bukhāri: Muḥaddith wa Faqīh (Mesir: Dār al-Qawmīyah li al-Ṭibā'ah wa al-Nashr, t.th.), 167.
} 
Hadith wa al-Figh. ${ }^{15}$ Ibn Rāhawayh adalah guru sekaligus motivator penulisan kitab al-Jāmi' al-Sạīh yang monumental.

Klaim pada al-Bukhārī sebagai pengikut mazhab tertentu adalah tidak tepat. Menanggapi klaim al-Subkī, C.E. Bosworth dalam The Encyclopaedia of Islam mengatakan "althought al-Subki includes al-Bukhari among the Shafi'i Faqihs, this is not accurate, for he did not bold consistently the doctrine of any particular school'. ${ }^{16}$ Penolakan Bosworth terhadap pendapat al-Subkī berdasar kenyataan bahwa al-Bukhārī tidak mengikuti mazhab tertentu secara konsisten. Pendapat-pendapat al-Bukhārī kadang berseberangan dengan pendapat mazhab Shāfí̄i, Mālikī, maupun Ḥanafī, meski terkadang juga sesuai dengan ketiganya atau sesuai dengan pendapat Sahabat dan Tābi īn.

Sejalan dengan Bosworth, Shaykh al-Islam Ibn Taymīyah, ${ }^{17}$ ketika ditanya tentang posisi sejumlah ahli hadīth seperti alBukhārī, Muslim, Abū Dāwūd, al-Tirmidhī, al-Nasā̄î, Ibn Mājah, Abū Dāwūd al-Ṭayālisī, al-Dārimī, al-Bazzār, al-Dār al-Quṭnī, alBayhaqīi, Ibn Ḥuzaymah, Abū Ya'lā al-Mūṣilī. Al-Bukhārī, bersama Abū Dāwūd, oleh Ibn Taymìyah disebut sebagai imam fiqh dan ahli ijtihad, dan tidak mengaitkan keduanya pada salah satu mazhab.

Sanggahan terhadap klaim keterikatan al-Bukhārī terhadap mazhab tertentu juga dikemukakan oleh al-Ḥusaynī 'Abd al-Majīd Hāshim, ${ }^{18}$ yang juga menolak klaim yang mengelompokkan alBukhārī sebagai pengikut mazhab tertentu, dan berpendapat bahwa al-Bukhārī adalah seorang mujtahid mutlak.

Kalau seorang murid harus menjadi pengikut mazhab gurunya, dan tidak bisa menjadi mujtahid sendiri, maka selamanya tidak akan ada mujtahid, bahkan imam mazhab yang empat itu pasti menjadi pengikut mazhab sebelumnya. Namun, realitasnya tidaklah demikian; al-Shāfí̄ pernah menjadi murid Mālik hingga hafal al-

\footnotetext{
15 Aḥmad b. 'Alī b. Hajar al-'Asqalānī, Fatḥ al-Bārì (Kairo: Dār al-Diyān li alTurāth, 1998), 8.

16 Clifford Edmund Bosworth, The Encyclopaedia of Islam, Vol. 1 (Leiden: E.J. Brill, 1986), 1297.

17 Al-Shaykh, al-Imām al-Bukhārì, 259.

18 Al-Husaynī, al-Imām al-Bukhārì, 168, 186-198.
} 
Muwatta', dan juga pernah belajar hadīth dari Ibn Hanbal; Mālik belajar fiqh pada Rabī'ah al-Ra'yi; Rabi'ah sendiri pernah belajar fiqh pada Abū Ḥanīfah; dan Abu Ḥanifah pernah belajar pada Ibrāhīm al-Nakha'î. Mereka bisa menjadi mujtahid mutlak, dan tidak menjadi pengikut mazhab gurunya. Mereka adalah mujtahid terkemuka, belajar pada beberapa ulama sebelumnya, kemudian mereka berijtihad sendiri, dan produk ijtihadnya bersesuaian dengan al-Qur'ān, al-Sunnah, athar dan pendapat Sahabat serta Tābi'īn, bersesuaian pula dengan ijmá' dan qiy às. Tersebarlah dari para ulama mujtahid tersebut pemikiran-pemikiran fiqh yang cemerlang bagi pembentukan hukum Islam.

Demikian pula al-Bukhārī, yang selain hafal al-Qur'ān, alSunnah, athar dan pendapat Sahabat serta Tābi în, ia juga memiliki pengetahuan yang luas di bidang fiqh. Ia dapat menggali pemikiran-pemikiran fiqh karena penguasaannya yang luas dan mendalam terhadap hadìth; ia dapat menggali hukum dari hadīth. Dengan ijtihad-ijtihadnya, al-Bukhārī telah menyinari khazanah intelektual keislaman dan hukum.

Selain argumentasi di atas, al-Husaynī juga mengemukakan bukti-bukti produk ijtihad al-Bukhārī yang kadang sama dengan salah satu mazhab tetapi berbeda dengan mazhab lainnya, seperti: a) Mengusap kepala dalam berwudu. Kepala yang dimaksud alBukhārī adalah seluruh bagian yang disebut kepala, sebagaimana nas menyebutkan kepala. Pendapat al-Bukhārī dalam hal ini sama dengan Mālik, berbeda dengan Shāfí̀̄, Abū Ḥanīfah (sebagian kepala), dan Ahmad yang memasukkan kedua telinga ke dalam bagian dari kepala; b) Bilangan mengusap kepala dalam wudlu, menurut al-Bukhārī, diwajibkan hanya satu kali. Pendapat ini sama dengan pendapat Abū Hanīfah, berbeda denggan Shāfíīic) Menyentuh perempuan tidaklah membatalkan wudu, sebab yang membatalkan wudu, menurut al-Bukhārīi, adalah bersenggama (aljimāo $)$. Pendapat ini berbeda dengan pendapat Shāfíí dan Mālik, tetapi sama dengan dengan Ḥanafî, Ibn 'Abbās, dan 'Alī b. Abì Ṭālib; d) Orang junub dan wanita menstruasi boleh membaca alQur'ān. Pendapat al-Bukhārī ini berbeda dengan jubür fuqabä' yang mengharamkan orang junub membaca al-Qur'ān, tetapi sama dengan pendapat Ibrāhīm al-Nakha'í (Tābi'în) dan Ibn 'Abbās (Sahabat); e) Orang yang melakukan hubungan suami-istri di siang hari di bulan Ramaḍān, wajib membayar kaffärah (denda), dan tidak 
wajib meng-qada' (mengganti) puasanya. Dalam hal ini al-Bukhārī berbeda dengan ulama Ḥanafìah, Mālikìyah, Shāfiłìyah, Ḥanābilah, dan lain-lain; f) Dalam masalah pembagian harta waris, berdasarkan hadīth "lā yarith al-Muslim al-käfir, wa là al-käfir al-Muslim", Hanafì dan Mālikī sependapat bahwa orang Islam tidak boleh menjadi pewaris dari orang kafir dan sebaliknya, sedangkan Shāfíi mempunyai pendapat berbeda, yaitu orang Islam boleh menjadi pewaris orang kafir, tetapi orang kafir tidak boleh mewarisi harta orang Islam. Dalam hal ini, al-Bukhārī konsisten terhadap teks hạaīth, bahkan dalam Șạ̄ị al-Bukhārī secara eksplisit menulis judul bab "Là yarith al-Muslim al-keäfir wa là al-käfir al-Muslim, wa idhā aslam qabl an yuqassam al-mirä̀th fa lä mìäth lab". Pencantuman judul bab tersebut mengindikasikan bahwa, menurut al-Bukhārī, orang kafir meskipun masuk Islam sebelum harta waris itu dibagikan, tetap tidak mendapat bagian. ${ }^{19}$

Dari uraian di atas, dapat diketahui bahwa asumsi yang menganggap bahwa al-Bukhārī adalah mujtahid fì al-madhhab tidaklah benar, karena al-Bukhārī tidak terpengaruh oleh atau terkait dengan mazhab manapun. Pemikiran hukum al-Bukhārī berkisar pada makna hadīth yang darinya ia menggali hukum, sehingga bisa saja sesuai dengan semua mazhab dan juga bisa berbeda dengan sebagian atau semua mazhab.

\section{Posisi al-Bukhārī sebagai Mujtahid}

Ulama usul telah merumuskan peringkat-peringkat mujtahid. Namun, di samping hasil rumusan tersebut berbeda-beda, juga tidak dapat diketahui secara pasti oleh siapa dan kapan rumusan itu ditetapkan sebagaimana yang ada sekarang. Rumusan tentang peringkat mujtahid kontemporer dikemukakan oleh Wahbah alZuhaylī sebagai berikut:

Pertama, mujtahid mustaqïl, yaitu mujtahid yang membangun fiqh atas dasar metode dan kaidah yang ditetapkannya sendiri, atau dengan kata lain, mujtahid tersebut memiliki usul fiqh dan fiqh-nya sendiri, yang berbeda dengan usul fiqh dan fiqh lain. Mujtahid pada peringkat ini adalah orang yang telah memenuhi syarat-syarat tertentu dan dapat secara mandiri mempergunakan dalil, tanpa terikat pada mazhab manapun. Mujtahid mustaqil, dalam tulisan al-

19 Abdul Sattar, "Konstruksi Fiqh Bukhari dalam Kitab al-Jami' al-Shahih", de Jure: Jurnal Syariah dan Hukum, Vol. 3. No. 1 (2011), 42-43. 
Ghazālī, al-Rāzī, dan al-Āmidī, diistilahkan dengan mujtahid mutlak. Imam mazhab yang empat merupakan contoh mujtahid yang termasuk dalam kategori ini. Al-Qaradaw $\bar{i}^{20}$ juga memasukkan para ahli fiqh dari Sahabat, Tābi'īn, dan orang-orang yang selevel dengan imam mazhab empat, seperti Zayd b. 'Alī Zayn al-'Ābidīn, Ja'far al-Ṣādiq, al-Thawrī, al-Awza'ī, Layth b. Sa'd, Dāwūd b. 'Alī, al-Tabarī, dan lain-lain.

Kedua, mujtabid mutlaq ghayr al-mustaqil, yaitu seorang mujtahid yang telah memenuhi syarat-syarat berijtihad, tetapi tidak memiliki metode istinbat sendiri, masih menggunakan metode istinbat imam mazhabnya. Namun demikian, mereka mandiri atau tidak terpengaruh oleh hasil ijtihad imam mazhabnya, dan dalam masalah furü'yyah, produk ijtihad mereka kadang-kadang berbeda meskipun kebanyakan sama. ${ }^{21}$ Dengan kata lain, mujtahid kategori ini mempunyai fiqh sendiri, sedang usul fiqhnya masih mengikuti imam mazhabnya. Contoh mujtahid dalam kategori ini antara lain: Abū Yūsuf (w. 183 H/798 M), Muhammad b. al-Ḥasan alShaybānī (w. 189 H/805 M), dan Zufar b. al-Hudhayl (w. 158 H/775 M), pengikut Abū Ḥanīfah; 'Abd al-Raḥmān b. al-Qāsim (w. 191 H/808 M), Abū Muḥammad 'Abd Allāh b. Wahhāb (w. 197 H/814 M), pengikut Mālik; Ismā‘îl b. Yahyyā al-Muzanī (w. 264 H/877 M), Abū Ya'qūb Yūsuf b. Yahyāa al-Buwayṭī (w. 231 H/848 M), dan al-Za'farānī (w. $306 \mathrm{H} / 878 \mathrm{M}$ ), dari kalangan pengikut alShāfíī; al-Qādī Abū Ya'lā b. Qudāmah, Aḥmad b. 'Abd Ḥalīm b. 'Abd al-Salām b. Taymiyah (w. 728 H/1328 M), Ibn al-Qayyim alJawzīyah (w. $751 \mathrm{H} / 1350 \mathrm{M}$ ), dari kalangan pengikut Aḥmad b. Hanbal. Menurut Abū Zahrah, bahwa Abū Yūsuf, al-Shaybānī, dan Zufar b. al-Hudhayl termasuk ke dalam mujtahid mustaqil. ${ }^{22}$ Demikian pula al-Muzanī, sahabat al-Shāfi ‘̄i, juga termasuk mujtahid mustaqūl menurut Abū Ishạ̄q al-Shirāzī. ${ }^{23}$

Ketiga, mujtabid muqayyad (mujtahid takhrī), yaitu orang yang telah memenuhi syarat-syarat berijtihad dan mampu menggali hukum

\footnotetext{
20 Al-Qaradāwī, al-Ijtihàd, 96.

${ }^{21}$ Wahbah al-Zuhaylī, Ușùl al-Fiqh al-Islàmì (Beirut: Dār al-Fikr, 1986), 1080.

22 Muhammad Abū Zahrah, Muḥạdarah fì Tärīkh al-Madhāhib al-Islāmīyah (Beirut: Dār al-Fikr, t.th.), 122-123.

${ }^{23}$ Muḥammad 'Alī al-Sāyis, Tārìkh al-Figh al-Islāmì (Beirut: Dār al-Fikr, 1990), 121.
} 
dari sumber-sumbernya, tetapi tidak mau keluar dari dalil-dalil dan pandangan imamnya. Namun demikian, dalam masalah-masalah yang tidak dibahas oleh imamnya, ia melakukan ijtihad dan menggali hukum sendiri untuk mengetahui ketentuan-ketentuan peristiwa yang terjadi dengan cara men-takhrij nas-nas atau kaidahkaidah yang dinukil dari imam mazhabnya. Mujtahid yang termasuk ke dalam peringkat ini antara lain: Ḥasan b. Ziyād (w. 240 H/854 M), al-Karkhī (w. 340 H/951 M), al-Sarakhsī (w. 418 H/1090 M), dari mazhab Mālikī; Abū Ishāàq al-Shirāzī (w. 476 H/1083 M), dan al-Mārwadī (w. 462 H/1069 M), dari mazhab Shāfíī.

Keempat, mujtahid tarjih, yaitu ahli fiqh yang berupaya mempertahankan mazhab imamnya, mengetahui dalil-dalil yang dijadikan dasar pendapat-pendapat imamnya, mampu mendeskripsikan, menganalisis, membuat kesimpulan, dan men-tarjih pendapat yang kuat dari imamnya dan pendapat-pendapat yang terdapat dalam mazhabnya, baik pendapat murid-murid imam mazhab tersebut atau ulama-ulama lainya. Mujtahid yang berada pada peringkat ini antara lain: al-Qudūrī (w. $427 \mathrm{H} / 1035 \mathrm{M}$ ) dan alMarghīnānī (w.594 H/1197M.) dari mazhab Ḥanafí.

Kelima, mujtahid futya (fatwa), yaitu ahli fiqh yang berupaya menjaga mazhabnya, mengembangkannya, dan mampu menguasai masalah-masalah yang mudah maupun yang sulit, mampu memberikan fatwa dalam batas-batas yang telah ditentukan oleh imam mazhabnya, tetapi lemah dalam bidang istidläl (pencarian dalil) dan analisis.

Demikianlah sejumlah pendapat yang telah dikemukakan oleh para ulama usul fiqh tentang peringkat-peringkat mujtahid, mulai dari yang tidak setuju pada pemeringaktan tersebut, seperti alShawkānī, hingga rumusan ulama kontemporer yang disusun sesuai dengan kebutuhan dan kecenderungan ijtihad pada masanya. Sampai di sini, pertanyaan yang penting diajuakan adalah di manakah posisi al-Bukhārī dalam tabaqāt mujtahid tersebut? AlHusaynī, setelah memperhatikan otoritas al-Bukhārī dalam berijtihad, menggali hukum shar ì dari dalil-dalil tafsìlì , sebagaimana yang ditunjukkan dalam al-Jämi al-Sahị h, ia berkesimpulan bahwa al-Bukhārī telah mencapai peringkat mujtahid tertinggi yaitu 
mujtahid mutlak. ${ }^{24}$ Senada dengan pernyataan al-Husaynī tersebut, R. Marston Speight memberikan komentar terhadap konten kitab al-Jämi" al-Sahinh, "it was intended to be a tool for study of jurisprudence, with many of the texts arranged according to te catagories of Islamic law; the heading of the different sections reveals the compiler's competence in jurisprudence. Although all four schools of sunni law consider bim to be one of their basic sources, he never identified with any particular school'. ${ }^{25}$ Konten al-Jämi' al-Șahīh memang sarat dengan muatan fiqh dan usul fiqh, sehingga dapat dijadikan instrumen untuk menggali metodologi penulisnya.

Aḥmad Amīn mengatakan bahwa al-Bukhārī secara jelas adalah seorang mujtahid shar', ia memiliki metode istinbat hukum sendiri. Pemikiran-pemikiran hukumnya kadang-kadang sesuai dengan mazhab Hanafì dan mazhab Shāfi ‘̄, tetapi tidak jarang pula berbeda dengan keduanya. Pada suatu waktu, ia juga memilih mazhab Sahabat atau Tābi'īn seperti Ibn 'Abbās, Mujāhid, 'Ața' dan lain-lain, seperti dalam masalah bolehnya orang junub membaca al-Qur'ān; bolehnya orang sakit yang takut menggunakan air yang dingin untuk bertayammum; bolehnya salat menggunakan sandal; penetapan hukum jual beli sesuai dengan 'urf; bolehnya mengajarkan al-Qur'ān pada Ahli Kitab, dan lain-lain. Hal ini membuktikan bahwa al-Bukhārī tidak terikat pada mazhab manapun. ${ }^{26}$

Pernyataan serupa dikemukakan oleh Abū Shuhbah, ${ }^{27}$ bahkan ia menambahkan bahwa al-Bukhārī bukanlah seorang muqallid (pengikut suatu mazhab). ${ }^{28}$ Menurut penelitiannya, yang arjaḥ (bisa dipercaya) adalah bahwa al-Bukhārī merupakan seorang faqīh (ahli hukum Islam), yang telah mencapai tingkatan mujtahid mustaqīl

\footnotetext{
${ }^{24}$ Al-Husaynī, Al-Imam al-Bukhari, 173-174.

25 Dalam Mircea Eliade (ed.), The Encyclopaedia of Religion, Vol. II (London: Collier Macmillan Publishers, 1993), 53.

26 Aḥmad Amīn, Duhạa al-Islàm, Vol. 2 (Kairo: Maktabat al-Nahḍah al-Miṣrīyah, 1974), 114.

27 Muhammad Abū Shuhbah, Fì Riḥāb al-Sunnah al-Kutub al-Sị̣hạb al-Sittah (Mesir: Majma‘ al-Buhūth al-Islāmīyah, t.th.), 64-65.

${ }^{28}$ Dalam istilah usūl, muqallid adalah tingkatan bermazhab yang paling bawah, yaitu mengikuti pendapat atau fatwa suatu mazhab tanpa mengetahui dasardasar hukumnya.
} 
(mandiri dalam metode istinbat dan penalaran hukum Islam), dan oleh karenanya tidak terikat pada mazhab manapun.

Sebagai mujtahid mutlaq mustaqil, menurut kriteria mujtahid yang diintrodusir al-Suyūțī, al-Bukhārī menempati peringkat mujtahid tertinggi, yang untuk mencapainya, seorang mujtahid disyaratkan memiliki metodologi istinbat sendiri. Pada titik ini, pertanyaan selanjutnya mucul; bagaimanakah konstruksi metodologi hukum al-Bukhārīi?

\section{Metodologi Fiqh al-Bukhārī}

Metodologi rumusan al-Bukhārī sesuai dengan keahliannya sebagai ahli hadīth, bahkan mirip dengan ciri khusus metodologi ahli hạāith pada umumnya. Namun demikian, ia memiliki karakteristik yang spesifik yang membedakan dirinya dengan para ahli hadìth lainnya. Untuk itu, beberapa metodologi rumusan alBukhārī akan dipaparkan berikut ini.

Pertama, lebih mengutamakan riwayat dari pada ra'yu. Al-Qurān ditempatkannya sebagai sumber hukum pertama, kemudian hadīth, athar Sahabat dan Tābiīn, baru kemudian yang terakhir adalah ra'yu. Komitmen al-Bukhārī terhadap riwayat bisa dilihat pada sistematika al-Jāmi' al-Saḅinh, di mana setiap bab (kitäb) selalu didahului dengan kutipan ayat-ayat al-Qur'ān, ${ }^{29}$ kemudian diikuti dengan hadīth sahih. Hal ini menjadi pembeda dengan, misalnya, Sahịị. Muslim, yang hanya berisi hadīth-ḥadīth nabi saja, meskipun susunan sistematikanya sama-sama menggunakan cara-cara kitab fiqh. Hal yang demikian ini turut membedakan karya al-Bukhārī dengan kitab-kitab Sunan, seperti Sunan Abū Däwüd, Sunan alNasä̀̄, Sunan al-Tirmidhì, Sunan Ibn Mäjah, dan lain-lain.

Analisis di atas menunjukkan bahwa al-Bukhārī tidak berarti menolak penggunaan ra'yu atau analogi. Dalam bab al-I'tisām bi alSunnab dan Akbbār al-Aḥad yang dimuat dalam bagian akhir al-Jāmi al-Ṣą̧ĭh, al-Bukhārī mengecam penggunaan ra'yu dan qiyās, dan menunjukkan otoritas hadīth ahad meskipun diriwayatkan oleh

\footnotetext{
${ }^{29}$ Kecuali bab (kitāb) yang di dalamnya tidak dijumpai ayat-ayat al-Qur'ān langsung diisi dengan ḥadīth-ḥadīth sahih. Hadìth-ḥadīth sahih yang dicantumkan lebih awal ini sebagai dasar hukum atas masalah yang dicantumkan dalam judul bab, dan hadīth-hadīth berikutnya sebagai sharḅ atau penjelas, misalnya hadìth yang dicantumkan pertama masih bersifat mutlak, maka hadīth berikutnya sebagi taqyid-nya atau sharh-nya.
} 
seorang perempuan. Kecaman al-Bukhārī terhadap penggunaan ra'yu dan qiyās tersebut, menurut Ignaz Goldziher, bukan berarti penolakan atas penggunaannya, melainkan sebuah upaya reduksi terhadap peran penting qiyas dan melimitasi penggunaannya. ${ }^{30}$

Ibn Hajar al-'Asqalānīin memberikan interpretasi pada bab yang mengecam penggunaan ra'yu dan qiyās dalam bab al-I tișäm tersebut. Menurutnya, yang dimaksud ra'yu adalah fatwa yang disampaikan atas dasar pendapat pribadi; yang dikecam adalah ra'yu yang bertentangan atau berbeda dengan nas, sedangkan ra'yu yang tidak bertentangan dengan nas, dan digunakan ketika tidak dijumpai dalam al-Qur'ān, al-Sunnah, dan ijmá', tidaklah dikecam. Demikian halnya penggunaan qiyās, apabila tidak dijumpai dalam al-Qur'ān, al-Sunnah dan ijmā' serta ada íllah yang jelas dan representatif, maka ia tetap diperlukan. Penggunaan qiyass yang dikecam adalah apabila dijumpai nas, atau ada nas, tetapi ditakwilkan dengan takwil yang tidak sesuai atau jauh menyimpang. Interpretasi Ibn Hajar dan pernyataan Ignaz Goldziher di atas, menunjukkan bahwa alBukhārī lebih mendahulukan nas dan riwayat (fatwa Sahabat dan Tābi'inn) dari pada ra'yu dalam istinbat hukum. Al-Bukhārī menempatkan ra'yu pada posisi keempat dalam sumber hukum Islam.

Kedua, tidak memisahkan antara furū̌r dengan asl-nya; antara fiqh dengan nas atau athar. Tidak seperti para fuqabä yang dalam tulisan-tulisannya tampak memisahkan fiqh dengan nas, ia menempatkan fiqh sebagai satu-kesatuan dengan nas, demikian pula tak bisa dipisahkan dari riwayat. Bunyi judul-judul yang terdapat dalam al-jämi' al-Sahich ${ }^{32}$ maupun dalam kitab-kitab susunannya yang lain, tak lain adalah wujud ekspresi dari pemikirannya. Untuk menyebut contoh, taruhlah subbab wajibnya imam dan makmum mambaca al-Fātiḥah dalam salat, baik di rumah maupun ketika

\footnotetext{
${ }^{30}$ Lucas, “The Legal Principles”, 292

31 Al-'Asqalānī, Fatḥ al-Bāri, Vol. 12, 296.

32 Terdapat perbedaan pendapat di antara kaum Muslim pereode awal tentang judul-judul bab dalam kitab al-Jāmi‘ al-Ṣaḥ̄h, apakah ditulis oleh al-Bukhārī sendiri atau diafiksasi (dibubuhi) oleh para transmitters (perawi) yang datang kemudian. Ibn Hajar al-'Asqalānī menegaskan bahwa judul-judul bab kitab alJämi' al-Sahịḥ tersebut hampir seluruhnya ditulis sendiri oleh al-Bukhārī. Lucas, "The Legal Principles", 293.
} 
bepergian, dalam salat jahr maupun sirr. ${ }^{33}$ Pada subbab tersebut, sebagai dasar bagi kewajiban membaca al-Fātihah dalam salat sirr maupun jahr bagi imam dan makmumnya, al-Bukhārī menyertakan hadìth-ḥadīth yang sahih.

Demikian halnya dalam kitab Khayr al-Kalàm fì al-Qiräah Khalf al-Imām, dibahas masalah bacaan makmum, di mana al-Bukhārī mengutip ayat al-Qur'ān (Q.S. al-Muzzammil [74]: 20, Q.S. al-Isrā' [17]: 78 dan Q.S. al-A'rāf [7]: 204), diikuti kutipan-kutipan hadīth dan athar yang jumlahnya mencapai 300 riwayat. Tidak ada pengantar maupun penjelasan terhadap masalah yang dibahas. Penjelasan cukup diberikan pada hadìth atau riwayat yang tidak mewajibkan makmum membaca al-Fātiḥah, itupun terbatas pada nilai hadīth yang dijadikan hujjah, apakah mursal atau munqati $r^{34}$ Jadi, hadìth-hadìth yang dicantumkan di bawah judul bab atau subbab tersebut merupakan landasan bagi pendapatnya, yang dinilai tidak perlu diterangkan lagi, karena hadīth-ḥadìth atau athar itu sendiri tak lain adalah keterangan yang tidak dapat diragukan.

Ketiga, memilih pendapat yang berdasar hạdīth lebih sahih atau sahih. Sebagai pakar hadīth yang yang memiliki bekal pengalaman mengumpulkan hadīth-hadìth sahih menjadi satu kitab al-jämi“ alal-Ṣąīh, serta telah meletakkan dasar penilaian kesahihan hadīth, al-Bukhārī memilih pendapat yang memiliki dasar hadīth lebih sahih atau sahih, dibanding pendapat Sahabat, Tābi'īn atau mujtahid yang memiliki dasar hadīth sahih atau tidak sahih, seperti pada persoalan mengangkat kedua tangan ketika mengucapkan kalimat takbir dalam salat. Al-Bukhārī meriwayatkan beberapa hadìth yang menyatakan bahwa nabi mengangkat kedua tangannya ketika takbirat al-ibram, ketika akan rukuk, ketika bangun dari rukuk, dan ketika berdiri dari duduk rakaat kedua. Ia juga meriwayatkan hadīth yang menyatakan bahwa nabi hanya mengangkat kedua tangannya pada takbirat al-ị̣räm saja, dan tidak

\footnotetext{
33 Muḥammad b. Ismāôil al-Bukhārī, al-jāmi al-Saḥihh, Vol. 1 (Semarang: Toha Putra, t.th.), 137-139.

${ }^{34}$ Al-Bukhārī, Khayr al-Kalàm fì al-Qiräah Khalf al-Imām (Beirut: Dār al-Kutub al'Ilmīyah, t.th.), 11. Dalam kitab ini dicantumkan hadīth-ḥadīth yang tidak sahih, tetapi diberi keterangan mengenai ketidak-sahihannya, dan dicantumkan pula pendapat Sahabat dan Tābi'īn, sedangkan pada al-jāmi‘ al-Sahịh, hanya memuat hadīth-ḥadìth nabi yang sahih saja, tidak ada athar Sahabat apalagi Tābi'īn.
} 
mengulangnya pada takbir-takbir berikutnya (hadīth ke 10 dalam Raf" al-Yadayn fí al-Salāh).

Dengan keahliannya di bidang hadīth, al-Bukhārī memilih hadìth yang mengangkat kedua tangan ketika takbir, rukuk, bangun dari rukuk, dan berdiri dari duduk setelah rakaat kedua, karena hadīthnya lebih sahih dari pada hadìth yang tidak mengangkat tangan. Ia mengatakan hadīth 'Ubayd Allāh b. Abī Rāfi' lebih sahih dari pada ḥadīth 'Așim b. Kulayb, meskipun keduanya sama-sama meriwayatkan hạaīth dari 'Alī b. Abī Ṭālib. Ia mengatakan bahwa apabila ada dua orang meriwayatkan hadìth, yang satu mengatakan ia melihat seseorang telah berbuat sesuatu, sedangkan yang lain tidak melihatnya, maka yang diterima adalah yang menyatakan melihat, karena yang menyatakan melihat itu dipandang sebagai saksi. Ia menganalogikan pada perkataan 'Abd Allāh b. Zubayr pada dua orang saksi, saksi pertama menyatakan bahwa ia mendengar pengakuan si Fulan bahwa ia mempunyai tanggungan 1000 dirham, sedangkan saksi kedua tidak mendengarnya, maka yang diterima adalah kesaksian saksi pertama. Demikian juga persaksian Bilāl yang melihat nabi salat di dalam Ka‘bah, sedangkan Faḍl b. al-'Abbas mengatakan sebaliknya, maka yang diterima adalah persaksian Bilāl. Al-Bukhārī juga menambahkan sikap tokoh ahli hadīth yang populer, Sufyān al-Thawrī, bahwa ketika disampaikan hadīth 'Așim b. Kulayb tersebut kepadanya, ia mengingkarinya.

Pada bagian awal periwayatan hadīth tentang mengangkat kedua tangan ini, al-Bukhārī memberikan komentar bahwa hạīith tersebut diriwayatkan oleh 17 orang Sahabat dan sejumlah ahli ilmu yang tersebar di beberapa negara. Hal ini menunjukkan komitmen al-Bukhārī pada pendapat yang berdasar pada hạaīth lebih sahih. ${ }^{35}$ Demikian pula, dalam masalah batalnya wudu, ia berbeda dengan al-Shāfi'ì dan Mālik, dan ia lebih sesuai dengan pendapat 'Abd Allāh b. 'Abbās, karena mempunyai dasar hạaīth yang sahih.

Keempat, pendapatnya diformulasikan dalam kalimat yang singkat. Dalam urusan fiqh, al-Bukhārī biasanya mengemukakan pendapatnya pada akhir pemaparan hadìth-ḥadīth dan dalam kalimat yang singkat, seperti komentarnya pada persoalan status

\footnotetext{
35 Al-Bukhārī, "Raf" al-Yadayn fì al-Ṣalāh", al-Maktabah al-Shāmilah; al-Majmū'ah 15 (t.th.), $1-7$
} 
aurat paha bagi laki-laki, dengan mengatakan: "wa hadith Anas asnad, wa hadith Jarhad ahwat" (hadith Anas [yang menyatakan paha bukan aurat] lebih sahih sanad-nya, sedangkan hadith riwayat Jarhad [yang menyatakan paha adalah aurat] lebih berhati-hati). ${ }^{36}$ Ia tidak terbiasa memberikan komentar panjang, karena pemaparan ayat dan hadìth-ḥadīth sudah dipandang cukup sebagai jawaban atau komentar. Namun demikian, apabila terjadi perbedaan riwayat, ia memberikan komentar singkat berdasarkan keahliannya di bidang hadīth dan ke-wara'-annya di bidang tasawuf.

Kelima, bersikap netral apabila terjadi perbedaan pendapat di antara Sahabat, Tābi īn, dan imam mujtahid, karena masing-masing mempunyai dasar yang kokoh, dan hadīth yang dijadikan dasar sama-sama sahihnya. Biasanya, al-Bukhārī berkomentar singkat seperti "al-ghusl ahwat?" (mandi junub lebih berhati-hati) ${ }^{37}$ dalam kasus sexual intercourse yang tidak sampai ejakulasi. Sikap netral alBukhārī ini tampak dalam beberapa kitab karyanya, misalnya Raf al-Yadayn fì al-Șalāh. Dalam kitab tersebut, al-Bukhārī tidak menyebut perbedaan pendapat di kalangan para ulama tentang mengangkat kedua tangan dalam salat. ${ }^{38}$ Padahal, perbedaan pendapat dalam masalah tersebut sangatlah beragam. Ia pun juga tidak tampak berpihak pada salah satu pendapat, melainkan hanya mengemukakan pendapat sesuai dengan hasil ijtihadnya sesuai dengan keahliannya di bidang hadīth, tanpa menyebutkan kesesuaiannya dengan pendapat ulama lain. Hal ini menunjukkan netralitas sikap al-Bukhārī, di samping kemandiriannya dalam ijtihad.

\section{Pembentukan Mazhab dan Kegagalan al-Bukhārī}

Jika al-Bukhārī menempati posisi sebagai mujtahid, bahkan pada tingkatan mutlak (mutlaq) atau mustaqil, lalu mengapa mazhab al-Bukhārī tidak pernah terekam dalam sejarah? Seorang mujtahid mutlak memang mempunyai kemampuan menggali hukum secara langsung dari sumber utamanya, yaitu al-Qur'ān dan Hadìth, serta memiliki metode istinbat sendiri, bahkan bukanlah hal yang mustahil dapat mendirikan mazhab sendiri, seperti murid-murid utama Abū Ḥanīfah (mazhab Ḥanafì), yaitu Abū Yūsuf, Muḥam-

\footnotetext{
36 Al-'Asqalānī, Fatḥ al-Bärì, Vol. 1, 570.

37 Al-Bukhārī, al-Jämi' al-Șaḥ̆h, Vol. 1, 63.

${ }^{38}$ Uraian lebih detail tentang masalah mengangkat tangan ini dapat dilihat dalam Ibn Rushd, Bidāyat al-Mujtahid, Vol. 1 (Beirut: Dār al-Fikr, t.th.), 96-97.
} 
mad b. al-Ḥasan al-Shaybān̄̄, dan Zufar b. Hudhayl; dan muridmurid Mālik b. Anas (mazhab Mālikī) seperti 'Abd al-Raḥmān b. al-Qāsim, 'Abd Allāh b. Wahhāb, 'Abd Allāh b. 'Abd al-Ḥakam dan lain-lain; juga al-Muzan̄i, murid al-Shāfi'ì (mazhab Shāficī). ${ }^{39}$ Selain itu, ulama muta'akbkhirin yang mempunyai kualifikasi mujtahid mutlak cukup banyak, antara lain 'Izz al-Dīn b. 'Abd alSalām, Ibn Daqīq al-'̄̄Id, Ibn Sayyid al-Nās, Zayn al-Dīn al-'Irāqī', Ibn Ḥajar al-'Asqalānī, al-Suyūṭī, al-Bulqīnī, Ibn Rif'ah, Ibn alHumām, Ibn al-Ḥājib, Ibn al-Qayyim al-Jawzìyah, al-Subkī, dan Ibn Taymiyah. ${ }^{40}$ Mereka adalah ulama-ulama yang tidak hanya menguasai ilmu yang dipersyaratkan sebagai mujtahid mutlak, tetapi juga menguasai ilmu-ilmu lainnya dengan sempurna. Namun demikian, sebagaimana halnya al-Bukhārī, mereka tidak berhasil mendirikan mazhab sendiri.

Ketidakberhasilan mereka dalam membangun mazhab sendiri, menurut Hallaq, ${ }^{41}$ dikarenakan kegagalan mereka dalam mengkonstruksi poros otoritasnya sendiri, sehingga terserap ke dalam poros otoritas yang telah mapan. Sebagai contoh, ulama Shāfíìyah seperti Abū Ibrāhīm Ismā̄îl b. Yahyā al-Muzanī al-Mișrī (w. 264 H/878 M), ${ }^{42}$ Abū al-Qāsim al-Anmātī (w. 288 H/901 M), Harmalah (w. 243 H/858 M) dan lain-lain, mempunyai kualifikasi mujtahid mutlak, berhasil mengembangkan doktrin dan metodologi hukum Islam sendiri dan namanya berhak dijadikan nama sebuah mazhab, tetapi karena mereka tidak berhasil membangun poros otoritasnya sendiri, maka mereka terserap ke dalam doktrin mazhab Shāfíī.

Selain itu, di kalangan mazhab Shāfíci, ada satu kelompok juris yang dikenal dengan sebutan "empat serangkai Muhammad", yaitu Muḥammad b. Nașr al-Marwazī (w. 294 H/906 M), Muḥammad b. Jarīr al-Tabarī (w. 310 H/922 M), Muhammad b. Khuzaymah alNaysābūrī (w. 311 H/923 M) dan Muhammad b. Mundhir alNaysābūrī (w. 318 H/930 M), yang sebenarnya berhak untuk

\footnotetext{
39 Zahrah, Muhāạdarah, 123; lihat juga al-Sāyis, Tārikh al-Fiqh, 121; dan Ḥasan Ahmad al-Khațib, Fiqh al-Islam (t.t.: t.tp., 1952), 379.

40 Yūsuf al-Qaradāwī, al-Ijtihād fì Shari ah al-Islämīyah, terj. Aḥmad Syatari (Jakarta: Bulan Bintang, 1987), 112.

${ }_{41}$ Wael B. Hallaq, The Origins and Evolution of Islamic Law (Cambridge: Cambridge University Press, 2005), 167-168.

42 Al-Sāyis, Tārikeh al-Fiqh, 121.
} 
membangun mazhab sendiri. Dari aspek pendukung berdirinya mazhab, mereka layak membangun mazhab atas namanya sendiri; memiliki doktrin dan metodologi sendiri; murid-murid mereka menerapkan doktrinnya di pengadilan-pengadilan dan mereka juga memimpin para hakim; bahkan mereka menjabat sebagai mufti; mereka mengajar doktrin hukum pada halaqah-halaqah yang diselenggarakan, tetapi mereka tidak berhasil membangun poros otoritas, sehingga akhirnya mereka terserap ke dalam poros mazhab Shāfíi ${ }^{43}$ Dari uraian di atas dan contoh-contoh yang diketengahkan sebagai bukti, maka dapat dipahami terserapnya alBukhārī ke dalam poros otoritas mazhab tententu dikarenakan ia tidak berhasil membangun poros otoritasnya sendiri.

Poros otoritas menunjuk pada seorang tokoh yang kemudian dikenal sebagai pendiri mazhab doktrinal, seperti Abū Ḥanīfah, Mālik, Shāfí̄, dan Ibn Hanbal. Pemegang poros otoritas ini kemudian disebut "imam" yang berkualifikasi sebagai mujtahid mutlak. Pengetahuan hukum para mujtahid ini sangat menyeluruh dan kreatif, dan mereka dipandang sebagai penempa metodologi mazhabnya yang menjadi dasar bagi pembentukan prinsip-prinsip hukum Islam, sehingga nama mereka menjadi label mazhabnya, dan diklaim sebagai pemrakarsanya.

Proses terbentuknya poros otoritas bermula dari munculnya suatu pendapat, teori, dan metodologi yang dibangun oleh seorang ulama terkemuka, yang pada gilirannya diikuti oleh masyarakat (mufti, qädì, ulama, dan masyarakat luas), baik yang semasa maupun hidup di masa berikutnya. Para mufti dan qā $\bar{d} \bar{i}$ ini, dalam menghadapi masalah-masalah sosial-keagamaan, mencoba mencari landasan dari pemikir sebelumnya yang dipandang mempunyai otoritas keilmuan. Proses ini, jika berlangsung secara terusmenerus dan diikuti oleh mufti, qädì, dan masyarakat, maka lahirlah sebuah mazhab. Dalam keadaan demikian, jika pandangan keilmuan itu kemudian semakin kuat dan mapan, legitimate, accountable secara keilmuan, dan menjadi panutan bagi generasi berikutnya, maka terbentuklah yang disebut "poros otoritas".

${ }^{43}$ Hallaq, The Origins and Evolution, 168. 
Pemikir atau ulama yang mempunyai otoritas keilmuan tersebut dikenal sebagi pendiri mazhab. ${ }^{44}$

Dalam sejarah perkembangan aliran keagamaan, baik teologi, hukum, maupun lainnya lebih dipengaruhi oleh adanya dua faktor, yaitu faktor politik dan loyalitas murid-muridnya. Faktor politik menunjuk pada adanya patronase pemerintah yang berkuasa terhadap suatu aliran, sehingga aliran tersebut tumbuh dan berkembang dengan subur. Mu'tazilah sebagai sebuah aliran teologi dalam Islam, pernah mencapai puncak perkembangannya, bahkan sempat menjadi mazhab resmi negara selama tiga periode pemerintahan Khalifah Ban̄̄ 'Abbās, yaitu mulai al-Ma'mūn (w. $218 \mathrm{H} / 833 \mathrm{M}$ ), al-Mu'tașim (w. $227 \mathrm{H} / 841 \mathrm{M}$ ), dan al-Wathīq (w. 232 H/847 M). Mazhab Sunnī yang juga disebut mazhab ahli hadīth, mazhab Salaf, dan aliran tradisional pernah berkembang pesat pada masa al-Mutawakkil (w. 247 H/861M). Dalam bidang hukum, mazhab Hanafī pernah berkembang pesat dalam tiga periode pemerintahan Khalifah Banī 'Abbās, yaitu sejak al-Mahdī (w. 169 H/785 M), al-Hādī (w. 170 H/786 M), hingga al-Rashīd (w. $193 \mathrm{H} / 809 \mathrm{M}$ ), sebagaimana pula mazhab Malikī berkembang atas dukungan al-Manșūr (w. 158 H/774 M), mazhab Shāfíī atas dukungan pemerintahan Șalāh al-Dīn al-Ayyūbī, dan mazhab Hanbalī atas dukungan al-Mutawakkil.

Menurut Hallaq, ${ }^{45}$ faktor politik ini merupakan faktor terpenting (paramount importance), yang menjadi legitimasi pemegang kekuasan, serta membentuk link antara rakyat dengan elit penguasa, di mana rakyat membutuhkan perlindungan dari penguasa, dan penguasa membutuhkan dukungan dari rakyat. Mazhab dipandang mempunyai peran yang sangat urgen dalam penciptaan kesadaran masyarakat. Oleh karena itu, mazhab yang mempunyai basis dukungan massa yang luas dijadikan mazhab resmi negara. Hubungan mazhab dengan penguasa merupakan hubungan simbiosis-mutualisme, di mana mazhab membutuhkan legitimasi politik dari penguasa dan sebaliknya. Kesuksesan mazhab Hanafi di Baghdad adalah karena mendapat perlindungan dari penguasa 'Abbāsìyah. Ulama mazhab Ḥanafĩ memperoleh dukungan massa

\footnotetext{
${ }^{44}$ Akh. Minhaji, "Otoritas, Kontinuitas, dan Perubahan dalam Sejarah Pemikiran Ushul al-Fiqh”, pengantar dalam Amir Mu'allim dan Yusdani, Ijtihad dan Legislasi Muslim Kontemporer, (Yogyakarta: UII Press, 2005), viii-ix.

${ }^{45}$ Hallaq, The Origins and Evolution, 169-170.
} 
yang besar, dan di beberapa daerah yang anti-'Abbāsīyah seperti di Syiria (sebuah wilayah 'Abbāsīyah yang masih loyal pada Umayyah), mazhab Hanafí gagal memperoleh dukungan. Mazhab Mālikī berkembang pesat di Andalūs (Spanyol saat ini) sekitar tahun 200-284 H, karena mendapat dukungan dari penguasa Umayyah di wilayah tersebut. Hal ini menunjukkan bahwa faktor politik memainkan peranan yang sangat urgen dalam perjalanan karir sebuah mazhab hukum.

Sementara itu, hal berbeda terjadi pada al-Bukhārī, yang dalam sejarah hidupnya mengalami perlakuan tidak menyenangkan dari penguasa, bahkan ia mengambil sikap tidak bersahabat dengan penguasa, sehingga kini menjadi jelas, mengapa doktrin dan metodologi yang dikonstruksi oleh al-Bukhārī tidak berkembang.

Faktor lain adalah tidak adanya pengikut/murid yang secara khusus mensosialisakan pemikiran-pemikiran al-Bukhārī di bidang fiqh. Tumbuh-kembangnya suatu aliran keagamaan, termasuk aliran pemikiran hukum Islam, banyak ditentukan oleh loyalitas murid-muridnya dan reputasi tokoh-tokohnya dalam menyampaikan dan mensistematisasikan pandangan-pandangan hukum yang mereka anut. ${ }^{46}$ Contoh terbaik dalam hal ini adalah Ibn Hanbal, imam mazhab Hanbalī yang sama sekali tidak meninggalkan tulisan-tulisan atau kitab fiqh, kecuali hanya kitab-kitab hadīth yang terkenal dengan sebutan al-Musnad, yang di dalamnya terhimpun 40.000 buah hadìth hasil seleksi dari 700.000 hadìth. Namun demikian, murid-murid Ibn Hanbal berusaha keras menghimpun fatwa-fatwa fiqhnya dalam berbagai persoalan, seperti Aḥmad b. Muhammad al-Khilāl yang mengumpulkan dan menuliskan fatwafatwa fiqh Ibn Hanbal hingga mencapai 20 jilid yang tebal-tebal lalu diberi judul al-Jāmi‘ al-Kabir. Banyak buku yang ditulis oleh murid-murid Ibn Hanbal, tetapi karya al-Khilāl ini merupakan kumpulan pikiran-pikiran fiqh Ibn Hanbal yang dinilai paling lengkap. ${ }^{47}$

Demikian halnya Abū Ḥanīfah, imam mazhab Ḥanafī, yang tidak meninggalkan kitab fiqh, kecuali al-Fiqh al-Akbar, yaitu kitab

\footnotetext{
46 Fathurrahman Djamil, Filsafat Hukum Islam (Jakarta: Logos Wacana Ilmu, 1997), 110.

${ }^{47}$ Abū Zahrah, Ibn Hanbal: Hayātuh, wa 'Așuh, wa Aràuh, wa Fiqhub (Mesir: Dār al-Fikr al-'Arabī, 1941), 37-38.
} 
tentang akidah. Kitab ini tidak membahas fiqh kecuali hanya sedikit sekali, yaitu tentang mengusap dua kbuf (sarung kaki) saja. Ia meninggalkan kitab hadīth yang diberi nama al-Musnad, berisi beberapa hadīth yang di antaranya diriwayatkan sendiri oleh Abū Ḥanīfah, yaitu sebanyak 215 hạaīth. ${ }^{48}$ Namun, murid-muridnyalah yang kemudian menghimpun dan menulis fatwa-fatwa serta pemikiran-pemikiran hukum Islam Abū Ḥanīfah ke dalam kitabkitab yang sistematis dan berjilid-jilid. Di antara murid-murid tersebut yang terkemuka adalah Muhammad b. al-Ḥasan alShaybānī dan Abū Yūsuf. Hal demikian pulalah yang terjadi pada para imam mazhab lainnya yang eksis dan berkembang hingga kini.

Hallaq menyebut tiga faktor keberhasilan atau tumbuhkembangnya mazhab di suatu daerah, yaitu (1) perolehan jabatan peradilan; (2) kemapanan halaqab; dan (3) pelibatan ulama-ulama lokal dalam perdebatan-perdebatan hukum Islam. ${ }^{49}$ Faktor pertama telah dikemukakan dalam bagian sebelumnya, bahwa jabatan qādi, mufti, atau lainnya dalam pemerintahan yang dijabat oleh penganut suatu mazhab, berarti memberi kesempatan pada mazhab yang bersangkutan untuk berkembang. Misalnya, pengangkatan Abū Yūsuf (112-183 H) murid terkemuka Abū Hanīfah, sebagai qā pada tiga periode pemerintahan Khalifah 'Abbāsīyah, sehingga mazhab Hanafí pun berkembang dengan pesat di Baghdad pada masa ini. Demikian halnya pengangkatan Ibn Hanbal sebagai pemberi legitimasi pengangkatan qädì pada masa pemerintahan alMutawakkil, dan mazhab Hanbalī pun menjadi kokoh. Namun, dari ketiga faktor ini, yang dinilai lebih efisien dalam penyebaran mazhab adalah kesuksesan anggota mazhab dalam membentuk bualaqah pengajaran, yang berarti mazhab yang bersangkutan mempunyai peluang lebih untuk berkembang melalui aktivitas para pengikutnya di masa yang akan datang.

Sementara itu, murid-murid al-Bukhārī, seperti Muslim, Abū Dāwūd, al-Nasa'̄i, dan al-Tirmidhī lebih dikenal sebagai ahli hadīth, meskipun mereka juga memiliki pengetahuan yang luas di bidang fiqh. Al-Bukhārī tidak mempunyai murid yang mempunyai perhatian serius terhadap fiqh. Murid-muridnya seperti tersebut di atas lebih peduli pada hadīth, meskipun al-Bukhārī mempunyai

\footnotetext{
48 Al-Sāyis, Tärikkh al-Fiqh, 106.

${ }^{49}$ Hallaq, The Origins and Evolution, 172.
} 
fatwa-fatwa dan pemikiran fiqh bahkan mewariskan beberapa buku di bidang fiqh, seperti Qadàyā al-Sahäbah wa al-Täbi ìn, Khayr alKalàm fì al-Qiräah Khalf al-Imām, dan Raf al-Yadayn fì al-Saläh. Namun, karena tidak memiliki murid-murid yang mengembangkan pemikiran-pemikiran hukumnya melalui halaqah-ḩalaqah atau media lainnya, maka pemikiran dan metodologi yang dikonstruksinya tidak memiliki kesempatan untuk berkembang, apalagi untuk membangun mazhab yang diatasnamakan dirinya, mazhab alBukhārī.

Di samping faktor keberhasilan di atas, Hallaq ${ }^{50}$ juga mengemukakan bahwa kegagalan eksistensi suatu mazhab disebabkan oleh empat faktor: Pertama, tidak memperoleh patronase politik pemerintah yang berkuasa. Kedua, kegagalan dalam mensintesakan rasionalisme dan tradisionalisme. Mazhab Zāhirī dan Abū Thawr menghilang karena kegagalan pada faktor ini. Kedua mazhab ini lebih cenderung tradisionalis, dan keterikatannya pada teks lebih kuat, sehingga tidak bisa meraup simpati massa yang besar. Demikian halnya pemikiran al-Bukhārī, keterikatan pada teks sangat intens, dan penggunaan qiyas sangat terbatas sekali, sehingga dipandang tidak cukup menarik untuk diikuti. Ketiga, tidak membangun aliansi dengan arus mainstream, dan bahkan melawannya, seperti hilangnya mazhab Ṭabarī dikarenakan sikap permusuhannya dengan mazhab Hanbalī yang telah mapan. Keempat, tidak memiliki ciri-ciri khusus sebagai pembeda yang menjadi identitas mazhabnya. Dalam hal ini, bisa dilihat mazhab Awza ${ }^{6} \overline{1}$ yang kehilangan pengikutnya yang cukup besar di Spanyol, karena Dinasti Umayyah di Spanyol mengadopsi mazhab Mālikī, meskipun keduanya dari aspek doktrin hukum tidak jauh berbeda. Dinasti Umayyah lebih memilih mazhab Mālikī, karena didorong oleh keinginan untuk tetap memakai mazhab hukum yang dibangun oleh orang-orang Madinah yang lebih awal. Kegagalan pembentukan mazhab al-Bukhārī, bisa jadi disebabkan oleh faktor keempat ini, mengingat metodologi dan prinsip-prinsip hukum alBukhārī tidak jauh berbeda dengan mazhab Ḥanbalī; komitmennya pada nas dan lebih mengutamakan riwayat dari pada ra'yu; serta penggunaan qiyàs yang sangat terbatas (qiyàs digunakan dalam keadaan terpaksa). Namun demikian, tidak tertutup kemungkinan

${ }^{50}$ Hallaq, The Origins and Evolution, 169-171. 
adanya faktor-faktor lain sebagai penyebab kegagalan pembentukan mazhab fiqh al-Bukhārī.

\section{Penutup}

Sebagai seorang mujtahid, ia tidak terikat oleh produk ijtihad dan metodologi ijtihad siapapun, karena ia telah membangun metodologi fiqh mandiri. Oleh karena itu, ia menempati posisi sejajar dengan para imam pemrakarsa mazhab, yaitu sebagai mujtahid mutlak. Bangunan metodologi fiqh yang ia bangun sejalan dengan keahliannya di bidang hadīth, dan oleh karenanya mirip dengan bangunan metodologi istinbat ahli hadīth pada umumnya. Namun, terdapat beberapa karakter spesifik, yaitu (1) lebih mengutamakan riwayat dari pada ra'yu; (2) tidak memisahkan antara furü dengan asl-nya, antara fiqh dengan nas atau athar, (3) memilih pendapat yang berdasar hadīth lebih sahih atau sahih; (4) pendapatnya diformulasikan dalam kalimat yang singkat; dan (5) bersikap netral apabila terjadi perbedaan pendapat di antara Sahabat, Tābi în, dan imam mujtahid.

Sementara itu, kegagalan al-Bukhārī dalam membentuk mazhab dikarenakan beberapa faktor, dan yang paling dominan adalah (1) faktor politik, yaitu tidak adanya patronase politik dari penguasa. Selanjutnya adalah (2) faktor loyalitas, di mana al-Bukhārī tidak mempunyai murid yang loyal untuk mengembangkan pemikiran fiqhnya. Kegagalannya dalam membentuk mazhab juga disebabkan oleh (3) komitmennya yang terlampau kuat pada teks, yang membuatnya tidak berhasil mensintesakan rasionalisme dan tradisionalisme secara proporsional (pemikiran fiqhnya cenderung tradisionalis). Al-Bukhārī juga (4) gagal dalam membentuk poros otoritas di bidang figh, dan hanya berhasil membangun poros otoritas di bidang hadīth. Faktor terakhir yang tak kalah penting adalah (5) tidak dimilikinya ciri pembeda yang khas, sehingga konstruksi metodologinya hampir sama dengan ahli figh pada umumnya, terutama mazhab Hanbalī.

\section{Daftar Rujukan}

Amīn, Aḥmad. Duhā al-Isläm, Vol. 2. Kairo: Maktabat al-Nahḍah al-Mișrīyah, 1974.

'Asqalānī (al), Aḥmad b. 'Alī b. Hajar. Fatḥ al-Bārì, Vol. 12. Kairo: Dār al-Diyān li al-Turāth, 1998. 
Azmi, Ahmad Sanusi. “Ahl al-Hadith Metodologies on Qur'anic Discourse in the Ninth Century: A Comparative Analisys of Ibn Hanbal and al-Bukhari", Online Journal Research in Islamic Studies, Vol. 4, No. 1, 2017.

Baghdādī (al), Aḥmad b. 'Alī al-Khațīb. Tārikeh Baghdād. Kairo: Maktabat al-Khanijī, 1931.

Bosworth, Clifford Edmund. The Encyclopaedia of Islam, Vol. 1. Leiden: E.J. Brill, 1986.

Bukhārī (al), Muḥammad b. Ismā'îl. al-Jāmi al-Ṣaḥị̣, Vol. 1. Semarang: Toha Putra, t.th.

----. "Raf" al-Yadayn fī al-Ṣalāh", al-Maktabah al-Shāmilab; alMajmū'ah 15, t.th.

-----. Khayr al-Kalàm fì al-Qirä'ah Khalf al-Imām. Beirut: Dār al-Kutub al-'Ilmiyah, t.th.

Deuraseh, Nurdeen. "Health and Medicine in the Islamic Tradition Based on the Book of Medicine (Kitab al-Tibb) of Sahih alBukhari", Journal of The International Society for History of Islamic Medicine (JISHIM), Vol. 5, No. 1, 2006.

Djamil, Fathurrahman. Filsafat Hukum Islam. Jakarta: Logos Wacana Ilmu, 1997.

Eliade, Mircea (ed.). The Encyclopaedia of Religion, Vol. II. London: Collier Macmillan Publishers, 1993.

Fanani, Afwan. "Al-Suyuti dan Kontroversi Strata Ijtihad: Telaah atas Klaim Mujtahid Mutlak al-Suyuti dan Landasan Normatifnya", Islamica: Jurnal Studi Keislaman, Vol. 2, No. 2, 2008.

Ghāmidī (al), Ibtisām b. Muḥammad b. Aḥmad. "Fiqh al-Imām alBukhārī fì al-Zakāh”. Tesis--Universitas Umm al-Qurā Mekah, t.th.

Husaynī (al), 'Abd al-Majīd Hāāshim. al-Imām al-Bukhārì: Muhaddith wa Faqīh. Mesir: Dār al-Qawmīyah li al-Ṭibā'ah wa al-Nashr, t.th.

Hallaq, Wael B. The Origins and Evolution of Islamic Law. Cambridge: Cambridge University Press, 2005.

Ibn Rushd. Bidāyat al-Mujtahid, Vol. 1. Beirut: Dār al-Fikr, t.th.

Khațīb (al), Ḥasan Aḥmad. Fiqh al-Isläm. t.t.: t.tp., 1952.

Lucas, Scott C. "The Legal Principles of Muhammad b. Ismā‘il alBukhārī and Their Relationship to Classical Salafi Islam", Islamic Law and Society, Vol. 13, No. 3, 2006. 
Marzuki. Kritik terhadap Kitab Șahīh al-Bukhärì dan Șahịh Muslim, HUMANIKA: Kajian Ilmiah Mata Kuliah Umum, Vol. 6, No. 1, 2006.

Minhaji, Akh. "Otoritas, Kontinuitas, dan Perubahan dalam Sejarah Pemikiran Ushul al-Fiqh", pengantar dalam Amir Mu'allim dan Yusdani. Ijtibad dan Legislasi Muslim Kontemporer. Yogyakarta: UII Press, 2005.

Muhibbin. "Telaah Ulang atas Kriteria Kesahihan Hadith-Hadith al-Jāmi‘ al-Ṣaḥih”. Disertasi--UIN Sunan Kalijaga Yogyakarta, 2004.

Qaḥtānī (al), Sa'īd b. 'Alī b. Wahf. Fiqh al-Da'wah fì Șahīh al-Imām alBukhāri. Mekah: Kementerian Wakaf, Dakwah, dan Irsyad, 1999.

Qaradāwī (al), Yūsuf. al-Ijtihāed fì Sharí ah al-Islamiỹah, terj. Aḥmad Syatari. Jakarta: Bulan Bintang, 1987.

Rumkhani (al), Asma at. al. "Tibbonto: Knowledge Representation of Prophet Medicine (Tibb al-Nabawi)", Procedia Computer Science, Vol. 82, 2016.

Sattar, Abdul. "Konstruksi Fiqh Bukhari dalam Kitab al-Jami' alShahih", de Jure: Jurnal Syariah dan Hukum, Vol. 3. No. 1, 2011.

Sāyis (al), Muḥammad 'Alī. Tārìkh al-Fiqh al-Islāmì. Beirut: Dār alFikr, 1990.

Shaykh (al), 'Abd al-Sattār. al-Imām al-Bukhāri: Ustädh al-Ustādhìn wa Imām al-Muḥaddithin wa Huijat al-Mujtabidin wa Ṣähib al-Jāmi' alMusnad al-Sahīḥ. Damshiq: Dār al-Qalam, 2007.

Shuhbah, Muḥammad Abū. Fī Riḥāb al-Sunnah al-Kutub al-Sịhhah alSittah. Mesir: Majma' al-Buhūth al-Islāmīyah, t.th.

Subkī (al), 'Abd al-Wahhāb b. Taqī al-Dīn. Tabaqat al-Shāfíryah alKubrā, Vol. 2. Mesir: al-Hasinīyah al-Mișrìyah, t.th.

Ya'lā, Ibn Abī. "Ṭabaqat al-Hanābilah", al-Maktabah al-Shāmilah, Edisi 2; al-Majmū'ah 46, Tarājim wa al-Ṭabaqah 15, t.th.

Zahrah, Abū. Ibn Hanbal: Hayātuh, wa 'Așrub, wa Arā'uh, wa Fiqhuh. Mesir: Dār al-Fikr al-'Arabī, 1941.

Zahrah, Muhammad Abū. Muḥādarah fi Tärīkh al-Madhāhib alIslāmìyah. Beirut: Dār al-Fikr, t.th.

Zuhaylī (al), Wahbah. Ușül al-Fiqh al-Islämì. Beirut: Dār al-Fikr, 1986. 